\title{
Elderly's attitude towards information communication technology
}

\author{
Jasna Špehar, Dajana Glavan, Dijana Došen, Andrej Starc \\ University of Ljubljana, Faculty of Health Science, Ljubljana, Slovenia \\ jasnaspehar@gmail.com, glavan.dajana@gmail.com, dijana.dosen1@gmail.com, andrej.starc@zf.uni-lj.si
}

\begin{abstract}
Introduction: Information and communication technology (ICT) is advancing extremely fast and is present at all stages of life. The need for the inclusion of ICT has also appeared in the everyday life of the elderly, which enables them easier access to new information and resources. Most older people were not directly involved in the new age of the Internet or the ICT, as they did not use computers or the Internet often in their educational, work and / or personal lives. Despite the fear of how the elderly will accept this, desires for knowledge and use have also started to come from their side, as they are interested in the benefits of ICT. Methods: A descriptive method with a systematic literature review was performed. The units for analysis took place with the help of DiKUL in the international databases Medline, ScienceDirect, CINAHL with full text and Google Scholar. We also searched using the COBIB.SI database. The keywords "elderly", "information and communication technology" and "health" with Boolean operators "AND" and "OR" were used in Slovene and in English. The inclusion criterion was also the content relevance. 19 articles were reviewed and after the content analysis, we ranked 10 articles. Subsequently, we excluded those articles that did not meet the inclusion criteria. Results: The use of ICT benefits the elderly, improves and facilitates daily activities. When problems arise in the use of ICT, they want the support and help of relatives. The elderly expressed fear of invasion of privacy and related security in the use of ICT. In the case of technology upgrades, they are concerned about whether they will be able to keep up with progress. The latter may be particularly exposed, as they also fear discrimination from society, which makes it easier to follow the progress of ICT development. In promoting the use of ICT in the elderly, the design of the devices must be taken into account, but also their social context. Discussion and conclusion: The number of elderly ICT users has been increasing.
\end{abstract}


Studies suggest positive effects of using ICT, especially to reduce feelings of loneliness. Restrictions on the cognitive and physical limitations of the elderly need to be taken into account when designing ICTs for the elderly. Older people may face special barriers to learning about ICT, the Internet and computers due to age-related sensory, physical and cognitive changes. Elderly people are often concerned about privacy when using ICT, but using it could partially relieve the health care system and help to detect health complications earlier and consequently reduce costs in the health care system. The attitude of the elderly towards ICT has important implications for the design and implementation of adapted forms of ICT related to health. New technology can to some extent replace the person caring for the elderly and give them a greater sense of independence and security.

Keywords: elderly, information communication technology, health, safety.

\section{Introduction}

Currently, almost a fifth of the European population is over 65 years old. The use of information and communication technology (ICT) is increasing rapidly (Monaco et al., 2019) and has recently become an integral part of life. It offers new tools that enable and facilitate daily activities and also lead to health improvements, as ICT provides older people with access to new information and resources. Those who use this technology are more likely to report better health. They want health-related ICT that provides them with independence, security and protection, and enables them to socialize, manage their own health, and assist them in their day-to-day activities (Kim et al., 2020).

Understanding the willingness of older people to adopt new technologies is one of the key components in determining which older people would benefit from ICT. Technologies are increasingly seen as a potential resource to facilitate or improve everyday life, as it is about adapting to aging and a particular environment (Courtney et al., 2008). Most of the literature refers to only one accepted type of technology, ignoring the fact that the use of a particular technology is highly dependent on the availability and use of technological and non-technological alternatives (Peek et al., 2019).

The aim of the article is to present the attitude of the elderly towards ICT.

\section{Methods}

We performed a systematic review of the literature using a descriptive method. The collection of units for analysis took place in March 2021 with the help of DiKUL and the international databases Medline, ScienceDirect, CINAHL with full text and Google Scholar. We also searched using the COBIB.SI database. 
In Slovene the keywords „zdravje“, „informacijsko komunikacijska tehnologija“ and „zdravje“ with Boolean operators „IN“ and „OR“ were used for the search. The keywords used in English were "elderly", "information communication technology" and "health" with Boolean operators "AND" and "OR".

The search was limited to a ten-year period of published units from 2011 to 2021. We have also used the language criterion, as only Slovenian and English scientific and professional articles with accessible full text were included.

The inclusion criterion was content relevance. We have reviewed 19 articles and we have ranked 10 articles after the content review. Subsequently, we excluded those articles that did not meet the inclusion criteria.

\section{Results}

Taking into account the inclusion criteria, five articles were included in the systematic literature review (Table 1). The results showed that the use of ICT benefits the elderly, improves and facilitates daily activities.

When problems arise with the use of ICT, help should be easily accessible to older people, both during training and during practical use. Lack of privacy, security and stigma are some of the barriers that older people face in using ICT (Vassli and Farshchian, 2017). There are six main interrelated factors related to the frequency of technology use, namely emotional attachment, compatibility of needs, signs of use, ability to use, resource input, and support (Peek et al., 2019). To promote the use of ICT in the elderly, broader contextual issues need to be considered, not only the design of devices but also their socio-ecological context (Abdelrahman et al., 2021).

\section{Table 1: Overview of analyzed articles}

\begin{tabular}{|c|c|c|c|}
\hline $\begin{array}{l}\text { Author, } \\
\text { year }\end{array}$ & $\begin{array}{l}\text { The purpose } \\
\text { of the research }\end{array}$ & Methodology & Results \\
\hline Peek et al., 2019 & $\begin{array}{l}\text { To better understand the } \\
\text { changes and frequency } \\
\text { of the use of ICT tech- } \\
\text { nology in independent } \\
\text { seniors. }\end{array}$ & $\begin{array}{l}\text { Longitudinal qualitative } \\
\text { Interview }\end{array}$ & $\begin{array}{l}\text { Regarding the frequency of } \\
\text { ICT use, there are } 6 \text { main in- } \\
\text { terrelated factors: } \\
\text { - emotional attachment } \\
\text { - compatibility of needs } \\
\text { - signs for use } \\
\text { - ability to use } \\
\text { - input of resources } \\
\text { - support }\end{array}$ \\
\hline $\begin{array}{l}\text { Ramsden Marston } \\
\text { et al., } 2019\end{array}$ & $\begin{array}{l}\text { To examine the experi- } \\
\text { ences of older people in } \\
\text { the field of ICT and the } \\
\text { impact on their lives. }\end{array}$ & $\begin{array}{l}\text { Online survey Focus } \\
\text { group }\end{array}$ & $\begin{array}{l}\text { They confirmed two inter- } \\
\text { twining themes: incentives } \\
\text { and barriers to use. They rec- } \\
\text { ommend promoting the use } \\
\text { of ICT according to the skills } \\
\text { of the elderly and opportu- } \\
\text { nities to improve health and } \\
\text { well-being. }\end{array}$ \\
\hline
\end{tabular}




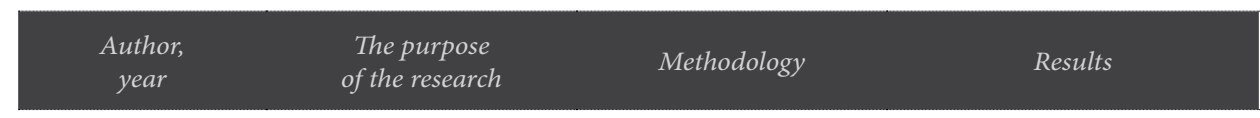

\begin{tabular}{|c|c|c|}
\hline $\begin{array}{l}\text { Abdelrahman et al., } \\
2020\end{array}$ & $\begin{array}{l}\text { To find out what are the } \\
\text { opinions about ICT re- } \\
\text { garding brain health in } \\
\text { healthy and independent } \\
\text { elderly people. Identify } \\
\text { the factors for the adop- } \\
\text { tion of ICT and its im- } \\
\text { portance for addressing } \\
\text { health issues. }\end{array}$ & $\begin{array}{l}\text { Qualitative research } \\
\text { method Focus groups } \\
\text { Content analysis }\end{array}$ \\
\hline
\end{tabular}

To find out what are the garding brain health in

Abdelrahman et al., the factors for the adopportance for addressing health issues.
Seven topics were identified: physical health, cognitive health, social engagement, information organization, desire to learn new technologies, technology development and privacy, and security. In order to promote the use of ICT in the elderly, it is necessary to take into account its socio-ecological context.

Caregivers perceived resistance, lack of interest, fear and their socio-social situation as an obstacle to ICT training in the elderly.

ICT instructors emphasized the importance of motivation, the instructor-elderly relationship, patience, self-confidence and mutual respect.

The elderly emphasized the achievements, challenges and sense of competence for ICT. An in-depth approach to addressing internal personal and external social barriers is crucial.

Older people want health-related ICT that provides them with independence, security and protection, enables them to socialize, manage their own health and helps them with their daily activities. Aid for the use of ICT must be easily accessible and adapted to the elderly. Barriers to the use of ICT are lack of privacy and security and stigma.

\section{Discussion}

Although most elderly people live in their own homes at an early age, they are not adapted to their changing needs. It is easier for ICT users to embrace it if it reminds them of a technology they have been using for many years (e.g. cable wires, standard telephones, etc.). Older people will invest energy and money for new technology as long as the latter is also beneficial to them (Lipar, 2014).

Recently, the number of elderly ICT users has been increasing. Studies suggest positive effects of using ICT, especially to reduce feelings of loneliness and depression. Little is known about the factors that would prevent the use of ICT in the elderly population, which may be at greater risk than those living in health and social care facilities (Rikard et al., 2018). 
The boom in ICT comes at a time of dramatic increase in life expectancy, which in turn leads to significant increases in healthcare costs. During this time, researchers are using the development and use of ICT in the healthcare environment, which would enable the improvement of health status and increase independence in everyday tasks.

ICT training can also encourage the elderly to increase the use of health and social care institutions, thus increasing the level of application skills, while promoting confidence in new technology and reducing the likelihood of discontinuing the use of ICT. A key factor that could contribute to the widespread applicability of ICT are designers and programmers, who should recognize limitations regarding the cognitive and physical limitations of the elderly (Rikard et al., 2018).

In a longitudinal survey on unobtrusive home monitoring and computer use, $72 \%$ of participants agreed with this type of study, but $60 \%$ expressed concerns about the privacy and security of personal data. The research included the installation of sensory technology at home and used it to determine the occurrence of cognitive decline and other health problems. The purpose of the study was to determine the level of readiness to share health and / or activity data with physicians or family members and to evaluate their privacy and data protection concerns (Boise et al., 2013). Concerns about data protection and security have been highlighted in several articles included in the systematic literature review. In a study by Boise et al. (2013) then, after one year, concerns about the potential risks to data privacy increased, while on the other hand, they perceived a high degree of agreement with such monitoring and sharing of information with the physician or family members.

Older people, to whom ICT is closer and more susceptible to it, could partially relieve the health care system by using it, thus helping to detect health complications earlier and consequently at a lower cost for the health care system. In healthcare, it is a well-known saying that prevention is better than treatment, not only in financial terms, but especially in terms of improving the quality of an individual's health, as prevention prevents many serious illnesses or injuries.

\section{Conclusions}

The older age group is not homogeneous in terms of display, income, or even the different types of disability that are often age-related. The elderly, like the group at greatest risk, will be excluded from the information societies. Most seniors were not directly involved in the development of the internet or ICT. Computers or the internet are not often used for their education, employees in / or personal life. Older people had to acquire ICT competencies in unfavourable conditions. Learn by having to collect with technologies that have so slowly supplanted manual activities in restaurants, shops, hospitals, and government affairs. Older people can earn age-related sensory, physical, and cog- 
nitive changes, encountering special hurdles in learning about ICT, the Internet, and computer science. There is a general belief that ICT can help older people improve their lives. They encourage them to stay healthier, live longer independently, if possible, to prevent impairment (Amaro and Gil, 2011). The attitude of the elderly towards ICT has important implications for the development of adapted forms of health-related ICT. New technology can make only a few substitutes that care for the elderly and give them more feelings of independence and security.

\section{References}

ABDELRAHMAN, N.G., HAQUE, R., POLVERENTO, M.E., WENDLING, A., GOETZ, C.M. and ARNETZ, B.B., 2021. Brain Health: Attitudes towards Technology Adoption in Older Adults [online]. Healthcare, vol. 9, no. 23, pp. 1-7. [viewed 1 April 2021]. Available from: http://dx.doi. org/10.3390/healthcarego10o23

AMARO, F. and GIL, H., 2011. ICT for Elderly People: »Yes, 'They' Can!«. In: 2011 e-CASE \& e-Tech International Conference, Tokyo, Japan, January 18-20, 2011. Toshi Center Hotel, pp. 3792-803. [viewed 1 April 2021]. Available from: https://www.researchgate.net/publication/277243287_ICT_ for_elderly_people_Yes_\%27They\%27_Can

ARTHANAT, S., VROMAN, K.G., LYSACK, C. and GRIZZETTI, J., 2019. Multi-stakeholder perspectives on information communication technology training for older adults: Implications for teaching and learning [online]. Disability and Rehabilitation: Assistive Technology, vol. 14, no. 5, pp. 453-61. [viewed 1 April 2021]. Available from: http://dx.doi.org/10.108 $\mathrm{o} / 17483107.2018 .1493752$

BOISE, L., WILD, K., MATTEK, N., RUHL, M., DODGE, H. H. and KAYE, J., 2013. Willingness of older adults to share data and privacy concerns after exposure to unobtrusive in-home monitoring [online]. Gerontechnology, vol. 11, no. 3, pp. 428-35. [viewed 1 April 2021]. Available from: https:// www.ncbi.nlm.nih.gov/pmc/articles/PMC3604979/pdf/nihms438588.pdf

COURTNEY, L.K., DEMIRIS, G., RANTZ, M. and SKUBIC, M., 20o8. Needing smart home technologies: the perspectives of older adults in continuing care retirement communities [online]. Informatics in Primary Care, vol. 16, no. 3, pp. 195-201. [viewed 1 April 2021]. Available from: http://dx. doi.org/10.14236/jhi.v16i3.694

KIM, J., LEE, J.H., WON, R.C., WON, R.C., BARR, T. and MERIGHI, J.R., 2020. Older adults technology use and its association eiyh health and depressive symptoms: Findings from the 2011 National Health and aging trends study [online]. Nursing Outlook, vol. 68, no. 5, pp. 56o-572. [viewed 1 April 2021]. Available from: https://dx.doi.org/10.1016\%2Fj.outlook.2020.05.001 
LIPAR, T., 2014. Tehnologija za starejše - gerontehnologija. Kakovostna starost [online], vol. 17, no. 1. [viewed 1 April 2021]. Available from: http://www. inst-antonatrstenjaka.si/tisk/kakovostna-starost/clanek.html?ID=1413.

MONACO, A., MAGGI, S., DE COLA, P., HASSAN, T.A., PALMER, K. and DONDE, S., 2019. Information and communication technology for increasing healthy ageing in people with non-communicable diseases: identifying challenges and further areas for development [online]. Aging Clinical and Experimental Research, vol. 31, no. 11, pp. 1689-1693. [viewed 1 April 2021]. Available from: https://dx.doi.org/10.1007/s40520019-01258-8

PEEK, S.T.M., LUIJKX, K.G., VRIJHOEF, H.J.M., NIEBOER, M.E., AARTS, S., VAN DER VOORT, C.S., RIJNAARD, M.D. and WOUTERS, E.J.M., 2019. Understanding changes and stability in the long-term use of technologies by seniors who are aging in place: a dynamical framework [online]. BMC Geriatrics, vol. 19, no. 236, pp. 1-13. [viewed 1 April 2021]. Available from: https://dx.doi.org/10.1186/s12877-019-1241-9

RIKARD, R.V., BERKOWSKY, W.R. and COTTON, R.S., 2018. Discontinued Information and Communication Technology Usage Among Older Adults in Continuing Care Retirement Communities in the United States [online]. Gerontology, vol. 64, no. 2, pp. 188-200. [viewed 1 April 2021]. Available from: https://www.ncbi.nlm.nih.gov/pmc/articles/ PMC5828954/pdf/nihms912583.pdf

RAMSDEN MARSTON, H., GENOE, R., FREEMAN, S., KULCZYCKI, C. and MUSSELWHITE, C., 2019. Older Adults' Perceptions of ICT: Main Findings from the Technology In Later Life (TILL) Study [online]. Healthcare, vol. 7, no. 86, pp. 1-27. [viewed 1 April 2021]. Available from: https://dx. doi.org/10.3390/healthcare7030086

VASSLI, L.T. and FARSHCHIAN, B., 2018. Acceptance of health-related ICT among elderly people living in the community: A systematic review of qualitative evidence [online]. International Journal of Human-Computer Interaction, vol. 34, no. 2, pp. 99-116. [viewed 1 April 2021]. Available from: https://dx.doi.org/10.1080/10447318.2017.1328024 